September 2003 - NREL/JA-560-34882

\title{
IEEE 1547 Series of Standards: Interconnection Issues
}

\section{Preprint}

T. Basso

R. DeBlasio

National Renewable Energy Laboratory

This work has been submitted to the IEEE for possible publication. Copyright may be transferred without notice, after which this version may no longer be accessible.

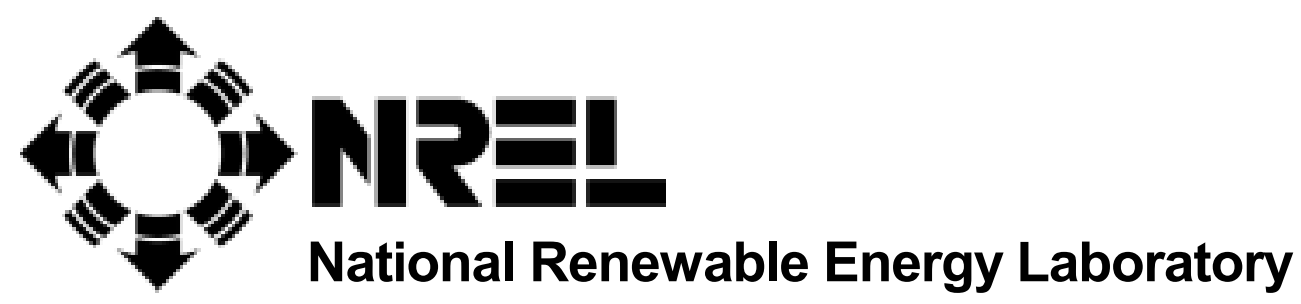

1617 Cole Boulevard

Golden, Colorado 80401-3393

NREL is a U.S. Department of Energy Laboratory

Operated by Midwest Research Institute • Battelle • Bechtel

Contract No. DE-AC36-99-G010337 


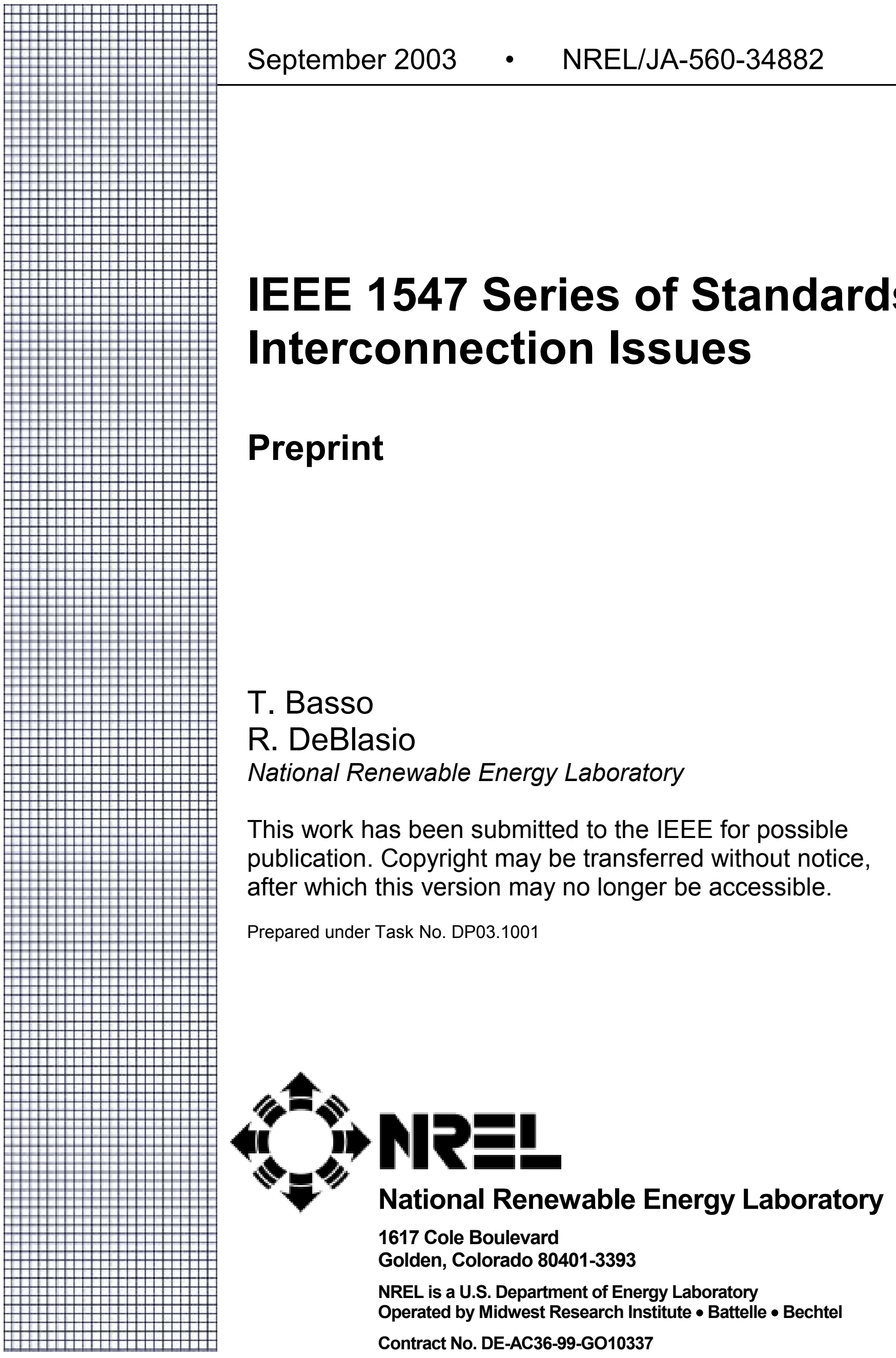


This work has been submitted to the IEEE for possible publication.

Copyright may be transferred without notice, after which this version may no longer be accessible.

\section{NOTICE}

This report was prepared as an account of work sponsored by an agency of the United States government. Neither the United States government nor any agency thereof, nor any of their employees, makes any warranty, express or implied, or assumes any legal liability or responsibility for the accuracy, completeness, or usefulness of any information, apparatus, product, or process disclosed, or represents that its use would not infringe privately owned rights. Reference herein to any specific commercial product, process, or service by trade name, trademark, manufacturer, or otherwise does not necessarily constitute or imply its endorsement, recommendation, or favoring by the United States government or any agency thereof. The views and opinions of authors expressed herein do not necessarily state or reflect those of the United States government or any agency thereof.

Available electronically at http://www.osti.gov/bridge

Available for a processing fee to U.S. Department of Energy and its contractors, in paper, from:

U.S. Department of Energy

Office of Scientific and Technical Information

P.O. Box 62

Oak Ridge, TN 37831-0062

phone: 865.576 .8401

fax: 865.576.5728

email: reports@adonis.osti.gov

Available for sale to the public, in paper, from:

U.S. Department of Commerce

National Technical Information Service

5285 Port Royal Road

Springfield, VA 22161

phone: 800.553 .6847

fax: 703.605.6900

email: orders@ntis.fedworld.gov

online ordering: http://www.ntis.gov/ordering.htm 


\title{
IEEE 1547 Series of Standards: Interconnection Issues
}

\author{
Thomas S. Basso, Member, IEEE, and Richard DeBlasio, Senior Member, IEEE ${ }^{l}$
}

\begin{abstract}
IEEE $1547^{\mathrm{TM}} 2003$ Standard for Interconnecting Distributed Resources With Electric Power Systems is the first in the 1547 series of planned interconnection standards. Major issues and a wealth of constructive dialogue arose during 1547 development. There was also a perceived increased vitality in updating complementary IEEE standards and developing additional standards to accommodate modern electrical and electronics systems and improved grid communications and operations. Power engineers and other stakeholders looking to the future are poised to incorporate 1547 into their knowledge base to help transform our nation's aging distribution systems while alleviating some of the burden on existing transmission systems.
\end{abstract}

Index Terms - certification; communications; distributed generation; distributed power; distributed resources; dispersed storage and generation; fuel cells; interconnection; monitoring and control; power systems; photovoltaic power systems; power distribution; power generation; regulation; standards; test.

\section{INTRODUCTION}

IEEE recently announced a new standard to help utilities tap surplus electricity from alternative sources: IEEE 1547 2003 Standard for Interconnecting Distribution Resources With Electric Power Systems. The standard establishes technical requirements for electric power systems (EPSs or electric grids) interconnecting with distributed generators such as fuel cells, photovoltaics, microturbines, reciprocating engines, wind generators, large turbines, and other local generators. Additional IEEE interconnection standards activities are now designated under the 1547 series of standards (Figure 1).

These standards are being developed under IEEE Standards Coordinating Committee 21 (SCC21) on Fuel Cells, Photovoltaics, Dispersed Generation, and Energy Storage. (See http://grouper.ieee.org/groups/scc21/ index.html.) Established by the IEEE Standards Association (IEEE SA), SCC21 sponsors standards projects, develops IEEE draft standards, and conducts coordination activities among individual IEEE societies. Specifically, SCC21 oversees the development of standards in the areas of fuel cells, photovoltaics, dispersed generation, and energy storage and coordinates efforts in these fields among the various IEEE societies and other effected organizations to ensure that all standards are consistent and properly reflect the views of all applicable disciplines. IEEE SCC21 reviews all proposed IEEE standards in these fields before they are submitted to the IEEE SA Standards Board for approval and coordinates submission to other organizations.

The 1547 standard focuses on the technical specifications for, and the testing of, the interconnection itself. It provides requirements relevant to the performance, operation, testing, safety, and maintenance of the interconnection. It includes general requirements, response to abnormal conditions, power quality, islanding, and test specifications and requirements for design, production, installation evaluation, commissioning, and periodic tests. The stated requirements are universally needed for the interconnection of distributed resources (DR), including synchronous machines, induction machines, and power inverters/ converters and will be sufficient for most installations.

The requirements are applicable to all DR technologies with aggregate capacity of $10 \mathrm{MVA}$ or less at the point of common coupling interconnected with EPSs at typical primary and/or secondary distribution voltages. Installation of DR on radial primary and secondary distribution systems is the main emphasis of the 1547 standard, although installation of DR on primary and secondary network distribution systems is also considered.

\section{BACKGROUND}

Traditionally, utility EPSs were not designed to accommodate active generation and storage at the distribution level. Corresponding to the multitude of utility companies are numerous types of EPS architectures based on differing designs and choices of equipment. The overall evolution of the grid has not been monolithic or based on a uniform approach to establish the most technically up-todate, integrated system. As a result, there are major issues and obstacles to an orderly transition to using DR with the grid.

The lack of uniform national interconnection standards and tests for interconnection, operation, and certification as well as the lack of uniform national building, electrical, and safety codes are understood. IEEE 1547 offers power engineers and other stakeholders a broad-based tool to help realize the grid of the future with various forms of DR effectively contributing to our electricity needs.

The development of 1547 has included arduous debate and scrutiny by hundreds of dedicated and experienced individuals. The names of 444 work and ballot group individuals appear in the front of the standard. The 1547

\footnotetext{
1 T. Basso is with the National Renewable Energy Laboratory, 1617 Cole Blvd., Golden, Colorado 80401 USA (e-mail: thomas_basso@nrel.gov). R. DeBlasio is with the National Renewable Energy Laboratory, 1617 Cole Blvd., Golden, Colorado 80401 USA (e-mail: deblasid@tcplink.nrel.gov).
} 


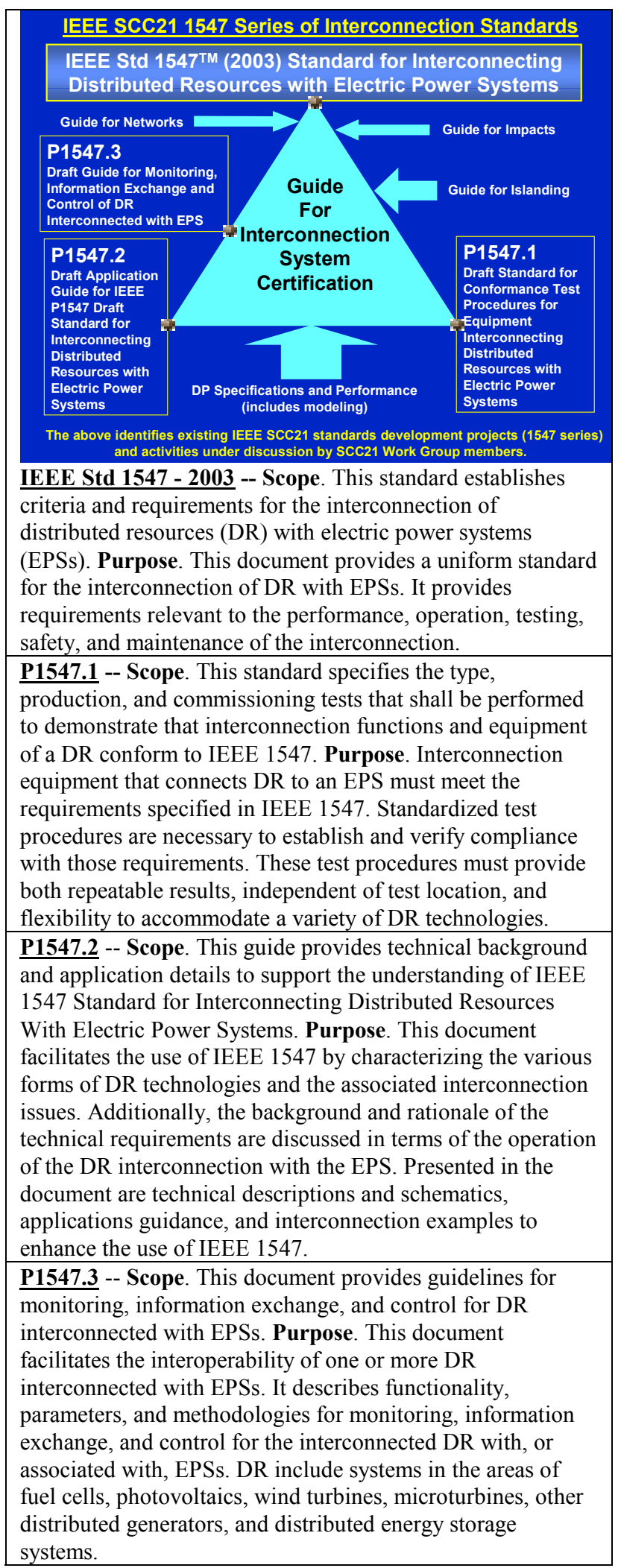

Figure 1. IEEE Interconnection Standards

(http://grouper.ieee.org/groups/scc21/dr_shared/) standard aims to be technology-neutral but cognizant that the technical attributes of DR and the types of EPSs do have a bearing on interconnection requirements.

The addition of DR to an EPS will change the system and its response in some manner. Although IEEE 1547 establishes criteria and requirements for interconnection, it is not a design handbook or an application guideline. The standard provides the minimum functional technical requirements universally needed to help ensure a technically sound interconnection. Any additional local requirements should not be implemented to the detriment of the functional technical requirements of the 1547 standard.

In addition, it is beyond the scope of the 1547 standard to address mitigating limitations of the Area EPS, methods used for performing EPS impact studies, or the business or tariff issues associated with interconnection. These aspects are more appropriate for complementary interconnection standards, technical papers, or further study.

\section{INTERCONNECTION ISSUES AND RESOURCES}

Prior to and during the development of 1547, numerous documents delineated major issues, obstacles, and approaches to an orderly transition to the interconnection of DR with the grid [1-4]. The 1547 work group minutes [5] and resource documents include voluminous amounts of technical information, documentation of standardized feedback, reviews of individual clauses/sections, recommended rewording, and reviewer rationales.

The interconnection guides and related documents of many utilities, manufacturers, and other stakeholders throughout the United States and Canada were used to establish 1547. Some of these publications were made freely available to 1547 work group members by the originating organizations, and some are resources for consideration during the development of the 1547 series.

During 1547 development, pointed discussions arose concerning specific issues that were not necessarily appropriate as universal mandatory requirements in the standard. These included many design-specific, applicationspecific, and equipment-specific issues as well as concerns broader than simple technical issues. The following two lists provide categorized summaries of the types of points that arose. Concerns more appropriately addressed external to a universal, mandatory requirements standards document - perhaps appropriate in a guide or special applications document - are system impacts and analysis (e.g., is it necessary and when); DR penetration (e.g., the ideal allowable aggregation); safety (e.g., functional versus operational modes); re-fitting of EPSs (e.g., what to do, cost of EPS re-fitting, and who pays); operation (e.g., which standard applies and who is in control); reliability (e.g., operational issues such as durability versus availability); federal/state implementation and effects (e.g., rules); misunderstanding or misapplication (e.g., limited experience or knowledge); and user disagreement (e.g., not all utilities and DG are alike). Broader DR interconnection concerns or R\&D issues not necessarily appropriate for a standard or perhaps not yet timely enough to be included in 
some form of a standard are after-sales service support and warranties; liability (e.g., DG operators versus grid operators); fully commercialized and certified products; full-scale remote or unattended operation (e.g., autonomous versus semi-autonomous); fully integrated controls and protective relaying (e.g., design and location); comprehensive functionality of the interconnection package (e.g., always more to add); where to include the interconnection capabilities (e.g., "black box," generator control); interface standards between DR and the interconnection package (e.g., equipment manufacturing design standards); issues of scaling to different power levels; and lower interconnection system cost.

\section{LOOKING FORWARD}

DR and uniform interconnection standards offer promise to help modernize and improve distribution system and related transmission system performance. When properly integrated with the grid, DR offer potential benefits including reduced electric line losses; reduced transmission and distribution congestion; grid investment deferment and improved grid asset utilization; improved grid reliability; ancillary services such as voltage support or stability, VARs, contingency reserves, and black start capability; clean energy; lower-cost electricity; reduced price volatility; greater reliability and power quality; energy and load management; and combined heat and power synergies.

In summary, these benefits tend toward the evolution of a modernized EPS with greater flexibility and energy security for the future. To realize significant penetration of DR and timely evolution of the existing EPS, further detailed standards and R\&D are needed on the key interface, interconnection, and communications and control technologies, including both hardware and software. Significant near-term, targeted load leveling may potentially be accomplished by accelerating the development, adoption, and implementation of improved regulatory utility policies, technical standards, local codes, and permitting processes that will facilitate DR integration with EPSs without compromising consumer protection, environmental values, health, and the safety and reliability of the grid.

State agencies and regional and federal government entities are developing interconnection agreement rules and protocols, including technical requirements. Such efforts to establish technical requirements including evaluation and testing procedures could benefit by referencing or incorporating IEEE standards as a technical foundation.

IEEE 1547 and its development are a model for ongoing success in establishing additional interconnection agreements, rules, and standards on national, regional, and state levels. IEEE 1547 has the potential to be used in federal legislation and rulemaking, state public utilities commissions deliberations, and the formulation of technical requirements for interconnection agreements by more than 3,000 utilities.

In the international arena, harmonization of IEEE and International Electrotechnical Commission (IEC) standards has always been an issue. Fortunately, harmonization of such standards may prove easier in the future. IEEE and IEC have agreed on a dual-logo arrangement for IEC to adopt IEEE electronics, telecom, and power generation standards for international use.

IEC Technical Committee 8 (TC 8) on System Aspects of Electrical Energy Supply has recently modified its scope and purpose. TC 8 prepares and coordinates the development of standards to facilitate the functioning of electricity supply systems, which encompass transmission and distribution networks and include interfaces with user installations (generators and consumers). The main system aspects include electrical system reliability, connection practices, operation, network responsibility, metering, data exchange and balancing, communication, characteristics of energy supply, and terminology. TC 8 also prepares basic IEC publications related to these aspects and ensures consistency among IEC publications related to its scope.

The US Technical Advisory Group for IEC TC 8 participation is being administered by the National Renewable Energy Laboratory. Along with the recent publication of IEEE 1547 and ongoing IEEE interconnection standards development support from working group members, this effort should help ensure US interests are carried forth in the global arena. International standards help improve global industrial efficiency, develop world trade, and provide the framework for economies of design, greater product and service quality, more interoperability, and better production and delivery efficiency. Further, IEC conformity assessment and product certification schemes at the national level ensure a certified product has been manufactured and type-tested to wellestablished international standards. The end-user is assured the product meets quality standards and need not be concerned with further testing or evaluation of the product.

\section{ACKNOWLEDGMENT}

The authors gratefully acknowledge the dedication and contributions of the members of the IEEE 1547 working and ballot groups, who volunteered their expertise and time to the success of IEEE standards development.

\section{REFERENCES}

1. ANSI/IEEE Std. 1001-1988, IEEE Guide for Interfacing Dispersed Storage and Generation Facilities With Electric Utility Systems (withdrawn 12/95).

2. Integration of Distributed Resources in Electric Power Systems: Current Interconnection Practice and Unified Approach, EPRI, Palo Alto, CA, TR-11489 (1998).

3. W.E. Feero and W.B. Gish, "Over-Voltages Caused by DSG Operation: Synchronous and Induction Generators," IEEE Transactions on Power Delivery, Vol. PWRD-1, Jan. 1986.

4. "Edison Electric Institute Distributed Resources Task Force Interconnection Study," Interconnection Working Group Chair M. Davis, June 2000.

5. http://grouper.ieee.org/groups/scc21/1547/archives/arch_min utes.html 
Thomas Basso (M 1980) is an engineer-scientist working at the National Renewable Energy Laboratory (NREL) under the Distribution and Interconnection R\&D area of the Distributed Energy and Electricity Reliability Program. Previously at NREL, he conducted outdoor accelerated weathering of photovoltaic modules and was project leader for PV Management under the NREL/DOE PV Advanced R\&D Project.

Before his work at NREL, he was a design engineer with a consulting engineering firm; with an OEM of air-cooled heat exchangers for the petrochemical, refinery, and utility industries; a standards engineer for the American Society of Mechanical Engineers (ASME); and an instructor in the Mechanical Engineering Department of Northeastern University. He serves as secretary of IEEE SCC21, P1547, P1547.2, and P1547.3 and is a member of IEC JCG DRES, IEC TC8, ASME, and the American Solar Energy Society.

Richard DeBlasio (M 1966, SM 1980) is technology manager of the NREL/DOE Distributed Energy and Electricity Reliability Program, which includes Distribution and Interconnection R\&D at NREL. Before joining NREL in 1978, he was with the U.S. Atomic Energy Commission in Washington, D.C., (1974-1978) and Underwriters Laboratories (19721974) and was a member of the technical staff at Stanford University (1965-1972). He is an electrical engineer; a senior member of IEEE; an IEEE SA Standards Board member; the IEEE Standards Coordinating Committee 21 on Fuel Cells, Photovoltaics, Distributed Power, and Energy Storage chair; and international standards committees IEC TC8 and $\mathrm{JC}$ chair. 


\section{REPORT DOCUMENTATION PAGE}

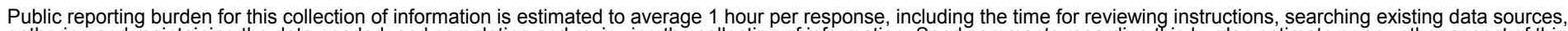

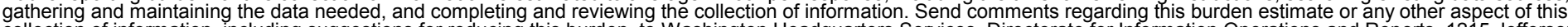

Washington Headquarters Services, Directorate for Information Operations and Reports, 1215 Jefferson

Davis Highway, Suite 1204, Arlington, VA 22202-4302, and to the Office of Management and Budget, Paperwork Reduction Project (0704-0188), Washington, DC 20503.
1. AGENCY USE ONLY (Leave blank)
2. REPORT DATE
September 2003
3. REPORT TYPE AND DATES COVERED Journal article preprint

4. TITLE AND SUBTITLE

IEEE 1547 Series of Standards: Interconnection Issues; Preprint

5. FUNDING NUMBERS DP03.1001

6. $\mathrm{AUTHOR}(\mathrm{S})$

T. Basso and R. DeBlasio

7. PERFORMING ORGANIZATION NAME(S) AND ADDRESS(ES)

National Renewable Energy Laboratory

1617 Cole Blvd.

Golden, CO 80401-3393

9. SPONSORING/MONITORING AGENCY NAME(S) AND ADDRESS(ES)

8. PERFORMING ORGANIZATION REPORT NUMBER NREL/JA-560-34882

10. SPONSORING/MONITORING AGENCY REPORT NUMBER

11. SUPPLEMENTARY NOTES

12a. DISTRIBUTION/AVAILABILITY STATEMENT

National Technical Information Service

12b. DISTRIBUTION CODE

U.S. Department of Commerce

5285 Port Royal Road

Springfield, VA 22161

13. ABSTRACT (Maximum 200 words)

IEEE $1547^{\mathrm{TM}} 2003$ Standard for Interconnecting Distributed Resources With Electric Power Systems is the first in the 1547 series of planned interconnection standards. Major issues and a wealth of constructive dialogue arose during 1547 development. There was also a perceived increased vitality in updating complementary IEEE standards and developing additional standards to accommodate modern electrical and electronics systems and improved grid communications and operations. Power engineers and other stakeholders looking to the future are poised to incorporate 1547 into their knowledge base to help transform our nation's aging distribution systems while alleviating some of the burden on existing transmission systems.

14. SUBJECT TERMS

1547; IEEE; standards; interconnection; distributed power; distributed energy; distributed generation; DP; DG; Distribution and Interconnection R\&D; National Renewable Energy Laboratory; NREL

17. SECURITY CLASSIFICATION OF REPORT Unclassified
18. SECURITY CLASSIFICATION OF THIS PAGE Unclassified
19. SECURITY CLASSIFICATION OF ABSTRACT Unclassified
15. NUMBER OF PAGES

16. PRICE CODE

20. LIMITATION OF ABSTRACT

UL 